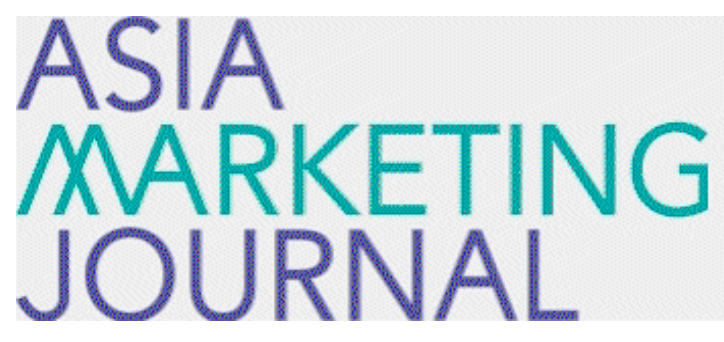

ASIA MARKETING JOURNAL

Volume 15 | Issue 4

Article 2

$1-30-2014$

\title{
Willingness to pay for eco-friendly products
}

Soon Hee Joung

Sun Wook Park

Yoon Jin Ko

Follow this and additional works at: https://amj.kma.re.kr/journal

Part of the Marketing Commons

\section{Recommended Citation}

Joung, Soon Hee; Park, Sun Wook; and Ko, Yoon Jin (2014) "Willingness to pay for eco-friendly products," Asia Marketing Journal: Vol. 15 : Iss. 4 , Article 2.

Available at: https://doi.org/10.53728/2765-6500.1565

This Article is brought to you for free and open access by Asia Marketing Journal. It has been accepted for inclusion in Asia Marketing Journal by an authorized editor of Asia Marketing Journal. 


\title{
Willingness to pay for eco-friendly products: case of cosmetics
}

\author{
Soon Hee Joung* \\ Sun Wook Park** \\ Yoon Jin $\mathrm{Ko}^{* * * *}$
}

Environmental concern has been an important issue for a few decades, and the extent of consumer demand for eco-friendly consumption has been increased. This study seeks to investigate consumers' willingness to pay (WTP) a premium for eco-friendly cosmetics. This study evaluates how much more a consumer is willing to pay for eco-friendly cosmetics and examines significant factors influencing consumers' WTP for eco-friendly cosmetics. Consumers' WTP is measured using four different ecofriendly cosmetics: low-priced skin care cosmetics, low-priced makeup cosmetics, high-priced skin care cosmetics, and high-priced makeup cosmetics. This study uses the contingent valuation method (CVM) to estimate consumer's WTP for eco-friendly cosmetics. Survey questions were designed using both dichotomous choice and payment card method of CVM.

Through face to face interviews and on-line surveys, the data were collected from women between 20 and 49 years old residing in Seoul and Kyeonggi area, Korea, in May 2010. A total of 226 questionnaires (132 from interviews and 94 from on-line) were included for the analytical sample in this study. The data were analyzed using descriptive analysis, T-test and Log-Logit analysis.

The findings are as follows:

First, the WTP measured by dichotomous choice method was estimated using the Log-Logit analysis. The results showed that the estimated WTP for low-priced skin care cosmetics was 19,152 won, which was 27.7\% higher than the reference price, 15,000 won. For low-priced makeup cosmetics, the estimated WTP was 18,524 won, and its green premium was 21.0\%. The estimated WTP for high-priced skin care cosmetics was 59,128 won, which was $18.3 \%$ higher than the reference price, 50,000 won. For high-priced makeup cosmetics was 57,666 won, and its green premium was $15.3 \%$.

Second, the WTP measure by payment card method was estimated using descriptive analysis. The results showed that the respondents were willing to pay 17,955 won for low-priced skin care cosmetics, which was 19.7\% higher than the reference price, 15,000 won and 17,595 won for low-priced makeup

\footnotetext{
* Professor, Dep. Of Consumer Studies, Ewha Womans University(jsh@ewha.ac.kr)

** Instructor, Dep. Of Consumer Studies, Ewha Womans University

*** Graduate Student, Dep. Of Consumer Studies, Ewha Womans University
} 
cosmetics, which was $17.3 \%$ higher than the reference price. For high-priced skin care cosmetics, the average WTP was 56,950 won which was 13.9\% higher than the reference price, 50,000 won. For high-priced makeup cosmetics, the average WTP was 55,650 won, which was $11.3 \%$ higher than the reference price. Overall, the WTP was higher in order of low-priced skin care, low-priced makeup, high-priced skin care, and high-priced makeup. It means that consumers decide degree of premium based on the price and the attributes of eco-friendly products.

Third, the findings showed that age, monthly income, and having children or not were statistically significant factors that influenced consumers' willingness to pay for eco-friendly cosmetics. Other explanatory variables such as education, marital status, job, purchase experience of eco-friendly products, and environmental concerns did not show any statistical significance.

The major contribution of this study is the investigation of the value of green attributes of the products by using CVM. Unlike most previous researches, this research used two methods of CVM, the dichotomous choice and the payment card, so it enhanced the reliability of research. According to this study, consumers showed price sensitivity when they pay green premium. These findings can be used as useful information to establish marketing strategies for green cosmetics.

Key words: Eco-friendly products, Willingness to pay, Cosmetics, Consumers, CVM, Log-Logit analysis, Green, Premium, Dichotomous choice method, Payment chard method

\section{Introduction}

In response to increasing concerns related to environment, consumers have considered the environmental aspects of the product. In the study of Kleiner(1991), 90 percent of American consumers stated that they considered the environmental impact of products and 75 percent reflected the environmental impact of products in their purchase decision. Chase \& Smith(1992) revealed 70 percent of respondents are 'sometimes' influenced by environmental message in advertising on their purchase decision. According to these findings, the government and corporations have assured possibility of new market and put out many green products on the market.

In the previous literatures investigating consumer's intention to purchase green products it is revealed that consumers showed a strong positive attitude on green products, however few green products have proved to be big sales successes (Landler, 1991; Alwitt, L. \& Pitts, R., 1996). Previous researches showed that green consumers who were environmentally conscious did not behave in accordance with their intention to purchase green products (Pearche, 1990, Ottoman, 1994).

Researchers tried to identify the cause of inconsistency of consumer's purchase intentions 
and their behavior. Chase and Smith(1992) reported that over fifty percent of consumers believed advertisings related to environments were greatly exaggerated. Follows and Jobber(2000) argued that most of the measures that measure environmentally responsible purchase behavior are normative and can lead to socially desirable responses. Questions such as 'How often do you recycle?' or 'Do you use your own cup instead of disposable cup?' estimate respondent's moral values as well. There are also effects of exogenous variables. For those reasons, consumer's purchase intention and actual behavior can be inconsistent with each other. Usitalo(1990) pointed out consumers made decision of purchase based on personal utility and they had a tendency to free ride on public goods such as environmental quality. Despite desiring environmental quality, consumers tried to avoid own sacrifices. He stated that the public goods' characteristics of environmental quality and consumers' free-rider behavior explained why environmentally responsible attitudes do not lead to people's actual choices on the market.

The production costs of green products are generally higher than general products. Therefore, the prices of green products are usually more expensive than general products (Lalit M Johri \& Kanokthip Sahasakmontry, 1998). The price differences between green products and general products have a negative effect on the growth of green market. Finally, questions about the proper level of green premium satisfying both companies and consumers remain.

This study focuses on the price of green products. High price of green products is one of the important reasons why consumers shun buy them. Finding out the appropriate level of the price satisfying both consumers and corporate may contribute to eliminate the barriers that prevent the growth of green market.

The purposes of this study are to:

- Find out consumers' willingness to pay(WTP) a premium for eco-friendly cosmetics products

- Analyze how much more an consumer is willing to pay for eco-friendly cosmetics

- Evaluate the demographic characteristics, purchase experience, and concerns on environment influencing consumer's willingness to pay a premium for eco-friendly cosmetics.

\section{Literature review}

\subsection{Contingent Valuation Method(CVM)}

CVM is one of the most widely used methods that estimate the value of attributes of the goods that are not traded in the market, such as environment-friendly products. The CVM uses survey questions to elicit people's willingness to pay for the good by finding out what they would be willing to pay for specified im- 
provements in them. The CVM is aimed at eliciting their willing ness to pay (WTP) in dollar amounts (Kim \& Jang, 2008).

The CVM first came into use in 1963 when economist Robert K. Davis used questionnaires consisting of the bidding game to estimate the benefits of outdoor recreation in Maine backwoods area. It began to be recognized as useful method after he found out that the amount of the willingness to pay measured by the CVM is similar with those measured by the travel cost model (TCM) which had been generally used for estimating the values of non-economic goods in that time.

In 1974, developing theoretical background of CVM, Randall(1974) infer maximum willingness to pay (MWTP) with the experimental design whereby certain aspect of the bidding game(Lee, 2006 recitation). The CVM has been the preferred valuation method mainly because of the endorsement it received from the NOAA's "blue ribbon" panel of experts on contingent valuation .

The CVM has been applied in extensive research area. In the researches of environmental economics and environmental policies the CVM has been used as the preferred methodology for measuring the willingness to pay for environmental goods. The CVM also has been used for evaluating the economic value of recreation area, natural scenery, the place and goods which have cultural, historical and ecological value. In recent the CVM has broadly applied for meas- uring the value of historical sites, art, and sport as well as family policies and leisure policies.

The CVM is usually estimate individuals' willingness to pay for non-market goods. The researcher describes the characteristics of the goods and hypothetical market settings and then the respondent answer the valuation questions. Because of hypothetical market settings, the CVM can infer the value of nonmarket goods, whereas, questions remain about reliability and validity of the research methods. Nevertheless, the CVM has been believed to give more accurate estimates for non-market goods than other valuation methods such as hedonic pricing method.

\subsection{Price Premium}

In previous researches, price premium was explained by the concept of information asymmetry and trust. First, information asymmetry has been at the heart of the traditional economic explanation for price premiums (Rao \& Bergen, 1992). When buyers cannot fully evaluate the quality of a product (information asymmetry), buyers (may) perceive that higherpriced products are of higher quality. Therefore, price premium is defined as the monetary amount above the price warranted by the 'true' quality of the product (Kim and Kim, 1999; Rao \& Bergen, 1992).

Second, in previous studies, price premium is considered as consumer's willingness to pay 
based on their trust in the product ( $\mathrm{Ha}, 2012$; Ba \& Conway, 2006). From this point of view, price premium is defined as the price that consumers are willing to pay more for a product that consumers can trust. Oberholtzer et al. (2005) found that consumers who have a positive attitude to eco-friendly products more tend to pay a price premium for ecological products. Thus, in this study, price premium is defined as the price that consumers are willing to pay more for eco-friendly products.

\subsection{Survey Design of CVM}

\subsubsection{Bidding Game}

The bidding game is modeled on the real-life situation in which individuals are asked to state a price - the auction (Lee, 2006 recitation). The respondents are asked whether they are willing to pay a premium for improving environmental qualities. If they answer yes, then the bid amount is continued to increase. The respondents are asked until they answer no. When they answer no, the bid price is the respondents' marginal willingness to pay (MWTP). The drawback of bidding game is that the first bid amount the researcher offers can be served as starting point bias.

\subsubsection{Open-ended question}

The respondents are asked how much you are willing to pay for the goods?' There are no price examples. Because there is no base price offered by the researcher, starting point bias can be removed. However, the respondents who have no purchase experiences and concerns of the goods are difficult to answer.

\subsubsection{Payment card method}

The payment card method was developed as an alternative to the bidding game. The question posed to the respondent is: "What amount on this card or any amount in between is the most that you would be willing to pay" for the level of good being proposed? The payment card method is potentially vulnerable to biases associated with the ranges used in the questions and the location of the benchmarks.

\subsubsection{Dichotomous choice method}

The dichotomous choice method for eliciting estimates of WTP has been widely used because of the advantage of this method: the respondent simply reacts to a posted price. Other arguments in favor of using dichotomous choice method are that a yes or no question in response to a posted price is less difficult for respondents to answer than an open-ended question. Also, respondents tend to be familiar with referenda. 


\subsection{Previous researches using contingent value method}

Contingent value method (CVM) is extensively used for researches investigating green market, because it is useful to measure consumer's purchasing intention in monetary term. In most studies, payment card method and dichotomous choice method are used as a method of contingent valuing.

First of all, in case of using payment card method, researchers divided consumer groups into several variables and conducted cross tabulation analysis (Huh and Kim, 2004). Using chi-square test, researchers verified the significance of the price differential among consumer groups. Researchers also investigated which consumer group has a high degree of purchasing intention. Then, researchers calculated the average of green premium and the reperence price to willingness to pay. Also, dichotomous choice method is one of the famous methods. In dichotomous choice method, respondents answer yes or no in whether they will pay in proposed price, so that data takes the form of binominal distribution. Therefore, by using binary logit analysis researchers can calculate willingness to pay and also find out the influences of variables.

The research of Huh and Kim(2004) estimated consumers' willingness to pay for environmentfriendly agricultural products by using payment card method of CVM. They divided environ- ment-friendly agricultural products into four groups such as grains, vegetables, fruits, and processed food and examined willingness to pay for each agricultural product. As a result, age and income variable showed no significant influences on consumers' willingness to pay for environment-friendly products. Region was only significant variable for willingness to pay a premium. In addition, it showed that consumers have more WTP on environment-friendly grains $(20.6 \%)$, vegetables $(20.2 \%)$, fruits $(19.3 \%)$, and processed food $(17.2 \%)$.

Kim and Jang (2008) investigated the WTP price of organic Korean beef using payment card method. According to this research, consumers in Seoul have 28.3\% more WTP on organic Korean beef. Also, it showed the higher average monthly income, the more WTP, and the older after 30s, the lower WTP.

Lee and et al. (2008) investigated WTP for U-Eco housing complex by using double bounded dichotomous choice method of CVM. This study showed that the WTP price per pyeong of Ahyen new town general housing complex was $17,090,000$ won and that of U-Eco housing complex was 18,790,000 won.

Researches of estimating consumer's WTP have been increasing. However, the subjects of researches are limited to public goods such as park and forest. There are a few researches focusing on consumer goods, but they are also limited to agricultural and fishery products. To vitalize green market, more researches estimat- 
ing consumer's WTP for diverse product groups are needed. Through increasing research on diverse consumer goods, it is possible to find the way, which can totally satisfy economy, environment, and consumers.

\section{Research method}

\subsection{The Rationale for The product}

In this study several product selection criteria are established in order to effectively measure consumers' willingness to pay a premium for green products. First, in order to effectively measure consumers' green premium, green attributes of the product should not provide direct economic benefits. If green attributes of the product provide direct economic benefits, this may cause consumer's preference for the product (Huh \& Kim, 2004). Because green attributes of the cosmetics don't provide direct economic benefits, the cosmetics is considered to be appropriate to estimate the willingness to pay a pure premium for green attributes.

Second, there should be no barriers to purchase green products and be easy to replace green products with non-green products so as to measure properly a green premium. For some green products, there are not enough distribution network, thus consumers have to visit a particular place to purchase the green products. In this case, purchasing barriers for green products could not induce the consumer's needs fully. On the other hand, the cosmetics market is relatively big in Korea, thus there are various kinds of distribution channels such as roadshops, hypermarket, and department stores. Also there are a lot of green cosmetic product lines and alternatives. Therefore, the cosmetics is recognized to be appropriate to estimate the willingness to pay for green products for this study(Yoo, Lee., \& Kim, 2011).

In order to accurately estimate the willingness to pay a premium, it is divided into two kinds of eco-friendly cosmetic products.

First, depending on the purpose of use, the cosmetic products were divided into skin care cosmetics and makeup cosmetics. According to the study of Shin(2007), the product attributes important for consumers were different between skin care cosmetics and makeup cosmetics. For skin care cosmetics, quality, functions, and the suitability of skin type were important for female consumers. However, for makeup cosmetics, aesthetic functions were the most important and the brand awareness was also considered.

Second, the products were divided into lowpriced products and high-priced products based on the price of reference products. The prices of cosmetics are significantly different depending on the distribution channels. There are low-priced cosmetics in road shops and big retailers and high-priced cosmetics in department stores. In this study the price of the reference 
product plays an important role as a benchmark because the prices of eco-friendly cos $^{-}$ metics are presented compared with the price of the reference products in questionnaires.

\subsection{Research questions}

RQ1. What is the consumers' willingness to pay a premium for eco-friendly cosmetic products?

This study uses dichotomous choice and payment card method of contingent valuing (CV).

RQ2. What are the factors related to how much more a consumers' willingness to pay for an eco-friendly cosmetics?

Consumers' willingness to pay for a premium is measured using four different eco-friendly cosmetics: low-priced skin care cosmetics, lowpriced make up cosmetics, high-priced skin care cosmetics, and high-priced make up cosmetics. In order to examine the important factors influencing consumers' willingness to pay, eight independent variables are included. They are six demographic variables such as age, job, educational level, income, marital status, having children or not, and a variable relate to experience of purchasing eco-friendly products and a variable relate to concerns on environment. The research question is analyzed by using Log-Logit model.

\subsection{Sample}

Data was collected (through survey) from 300 women between 20 and 49 years old residing in Seoul and Kyeonggi area, Korea between May 15, 2010 May 31, 2010. In order to get an accurate measure of individual's willingness to pay for eco-friendly products, it is important to reduce the bias of the response and describe the product in detail to the respondents. Thus, this study used the face to face interviews and on-line surveys. On-line surveys were carried out for respondents' convenience. A total of 300 questionnaires were distributed and 248 usable questionnaires were returned. Finally, 226 questionnaires (132 from interviews and 94 from on-line) were included for the analytical sample in this study.

\section{Results}

Quality satisfaction and repurchase intention on eco-friendly cosmetics

The study respondents are moderately satisfied with the quality of eco-friendly cosmetics $($ Mean $=3.40)$. The satisfaction questions were measured on a 5-point Likert scale. Over 84 percent of the respondents stated that they were willing to repurchase eco-friendly cosmetics. T-test revealed that quality satisfaction on eco-friendly cosmetics differentiated the two 
groups in a statistically significant way. Results from t-test indicated that the respondents who expressed repurchase intention were more satisfied with the qualities of eco-friendly cos- $^{-}$ metics (see. Table 1).

\subsection{Analyzing WTP (Willingness to pay) for eco-friendly cosmetics}

\subsubsection{WTP of dichotomous choice method}

The WTP value is estimated from regression coefficient calculated by Log-Logit function. The function of difference of indirect utility set for calculating the parameter for estimating the value of green cosmetics is as in the following.

$$
\Delta \nu=f \text { (AGE, EDU, INCOME, MARRIED, }
$$

$$
\text { CHILD, EXP, GREEN, JOB) }
$$

The explanation of dependent variable and independent variables are presented in Table 2.

In the logit model, the dependent variable is the willingness to pay for eco-friendly cos$^{-}$ metics and the independent variables are age (AGE), educational level(EDU), monthly income(INCOME), marital status(MARRIED), having children or not(CHILD), purchase experiences (EXP), green consumer or not (GREEN), and job (JOB).

The Log-Logit analysis was conducted to estimate WTP of eco-friendly cosmetics, using dichotomous choice of CVM. The results of analysis are presented in Table 3.

T-test was conducted on each independent variable and Log likelihood test was conducted on the model. Goodness of fit of the model (see the value of Model $\mathrm{x}^{2}$ ) showed that all 4 dependent variables distinguished by the product attributes and prices were statistically significant.

According to the result, in terms of $\mathrm{ex}^{-}$ planatory variables influencing the WTP, income, having children or not, and age were statistically significant on above 95 percent confidence level. In contrast, educational level, marital status, purchase experience, green consumer or not, and job have no influence in WTP. The prices offered in question (Bid_Offer) were statistically significant on all four products with 90 percent confidence level. Because the sign of the coefficient of Bid_Offer turns out negative, which means that the higher the Bid Offer is, the less the WTP is, it is accord with

〈Table 1〉 Comparison between Quality Satisfaction and Repurchase Intention

\begin{tabular}{c|c|c|c}
\hline Repurchase Intention & Yes & No & t-value \\
\hline Qualisfaction Satisfaction & 3.47 & 3.00 & $2.402 *$ \\
\hline$* p<.05$
\end{tabular}


〈Table 2〉 Using Variables in Dichotomous Choice Logit Model

\begin{tabular}{|c|c|c|c|c|}
\hline \multicolumn{2}{|c|}{ Variables } & Explanation & Mean & $\mathrm{SD}$ \\
\hline $\begin{array}{l}\text { Dependent } \\
\text { Variable }\end{array}$ & WTP & \multicolumn{3}{|c|}{$\begin{array}{l}\text { Willingness To Pay for Green Cosmetics } \\
\qquad(0=\mathrm{No}, 1=\mathrm{Yes})\end{array}$} \\
\hline \multirow{8}{*}{$\begin{array}{l}\text { Explanatory } \\
\text { Variable }\end{array}$} & Age & 1. $20 \mathrm{~s} / 2.30 \mathrm{~s} / 3$. Over $40 \mathrm{~s}$ & $\begin{array}{c}26.5 \\
(1.65)\end{array}$ & $(0.70)$ \\
\hline & Education & $\begin{array}{l}\text { 1. Under High School Graduation / } \\
\text { 2. Graduation Of University / } \\
\text { 3.Over Graduate School }\end{array}$ & 2.82 & 1.92 \\
\hline & Income & $\begin{array}{l}\text { 1. Under } 1,500,000 \text { won / } \\
\text { 2. } 1,500,000 \sim 3,000,000 \text { won / } \\
\text { 3. } 3,000,000 \sim 4,500,000 \text { won / } \\
\text { 4. } 4,500,000 \sim 6,000,000 \text { won / } \\
\text { 5. } 6,000,000 \sim 7,500,000 \text { won / } \\
\text { 6. Over 7,500,000won }\end{array}$ & $\begin{array}{c}3,270,000 \\
(31,800)\end{array}$ & $(12,800)$ \\
\hline & Marital Status & 0. Unmarried / 1. Married & 0.47 & 0.50 \\
\hline & Raising Children & 0. No / 1. Yes & 0.23 & 0.42 \\
\hline & Purchasing Experience & 0 . No / 1. Yes & 0.55 & 0.49 \\
\hline & Green or Non-green & $\begin{array}{l}\text { 0. Non-green Consumer / } \\
\text { 1. Green Consumer }\end{array}$ & 1.52 & 0.5 \\
\hline & Job & $\begin{array}{l}\text { 1. Student / 2. Housewife } \\
\text { 3. Non-Specialized Job / } \\
\text { 4. Specialized Job }\end{array}$ & & \\
\hline
\end{tabular}

the economic theory.

To calculate the average WTP of eco-friendly cosmetics per person, E(WTP), the following formula(1) is used.

$$
W T P_{\text {truncated }}=\int_{0}^{A^{i s s a x}} F(\Delta V) d A
$$

The respondents' WTP for eco-friendly cos- $^{-}$ metics are presented in Table 4. The price of the reference product was 15,000 won. The results showed that green premium of eco-friendly cosmetics was $27.7 \%$ for low-priced skin care cosmetics, $21.0 \%$ for low-priced makeup cosmetics, $18.3 \%$ for high-priced skin care cos$^{-}$ metics, and $15.3 \%$ for high-priced makeup cosmetics.

\subsubsection{WTP of payment card model}

In this study, the average WTP of ecofriendly cosmetics distinguished by the product attributes and prices is presented in Table 5.

On average, the respondents were willing to 
〈Table 3〉 Log-Logit Model for WTP of Dichotomous Choice

\begin{tabular}{|c|c|c|c|c|c|c|c|c|c|}
\hline \multirow{2}{*}{\multicolumn{2}{|c|}{ Variables }} & \multicolumn{2}{|c|}{$\begin{array}{l}\text { Low priced } \\
\text { Skin Care }\end{array}$} & \multicolumn{2}{|c|}{$\begin{array}{l}\text { Low priced } \\
\text { Make up }\end{array}$} & \multicolumn{2}{|c|}{$\begin{array}{l}\text { High priced } \\
\text { Skin Care }\end{array}$} & \multicolumn{2}{|c|}{$\begin{array}{l}\text { High priced } \\
\text { Skin Care }\end{array}$} \\
\hline & & coef. & t & coef. & t & coef. & t & coef. & t \\
\hline \multicolumn{2}{|c|}{$\begin{array}{c}\text { BID } \\
\text { OFFER }\end{array}$} & -.038 & $-9.52^{* * *}$ & -.30 & $-8.91^{* *}$ & -.024 & $-8.16^{*}$ & -.016 & $-7.94^{* * *}$ \\
\hline \multicolumn{2}{|c|}{ Age } & .008 & $.52^{*}$ & .007 & $.49^{*}$ & .002 & $.31^{*}$ & .001 & $.29 *$ \\
\hline \multicolumn{2}{|c|}{ Education } & -.173 & -.62 & -.147 & -.49 & -.281 & -.94 & -.181 & -.76 \\
\hline \multicolumn{2}{|c|}{ Income } & .472 & $3.63^{*}$ & .486 & $3.92^{* * * *}$ & .693 & $5.28 * * *$ & .566 & $4.49^{*}$ \\
\hline \multicolumn{2}{|c|}{ Marital Status } & .079 & .48 & .066 & .37 & .081 & .52 & .079 & .48 \\
\hline \multicolumn{2}{|c|}{ Raising Children } & .709 & $4.15^{* * * *}$ & .687 & $3.88^{* * * *}$ & .814 & $5.46^{* *}$ & .721 & $4.35^{* * * *}$ \\
\hline \multicolumn{2}{|c|}{$\begin{array}{c}\text { Experience of } \\
\text { Purchasing }\end{array}$} & -.017 & -.65 & -.011 & -.58 & -.028 & -.91 & -.014 & -.61 \\
\hline \multicolumn{2}{|c|}{$\begin{array}{c}\text { Green or } \\
\text { Non-green }\end{array}$} & .041 & .17 & .035 & .13 & .032 & .11 & .026 & .09 \\
\hline \multirow{4}{*}{ Job } & 1 & -.65 & -1.34 & -.42 & -.93 & -.72 & -1.57 & -.51 & -1.09 \\
\hline & 2 & -.64 & -1.91 & -.58 & -1.14 & -.51 & -1.02 & -.49 & -.98 \\
\hline & 3 & -.36 & -.79 & -.42 & -.89 & -.28 & -.79 & -.27 & -.79 \\
\hline & 4 & -.27 & -.66 & -.46 & -.95 & -.37 & -.81 & -.31 & -.72 \\
\hline \multicolumn{2}{|c|}{ Constant } & -.118 & -.16 & -.117 & -.15 & -.115 & -.10 & -.114 & -.10 \\
\hline \multicolumn{2}{|c|}{ Model $x^{2}$} & \multicolumn{2}{|c|}{$94.852(\mathrm{p}<0.1)$} & \multicolumn{2}{|c|}{$94.852(\mathrm{p}<0.5)$} & \multicolumn{2}{|c|}{$94.852(\mathrm{p}<0.1)$} & \multicolumn{2}{|c|}{$94.852(\mathrm{p}<0.1)$} \\
\hline \multicolumn{2}{|c|}{$\begin{array}{l}\text { Log Likelihood } \\
\text { Function }\end{array}$} & \multicolumn{2}{|c|}{-154.683} & \multicolumn{2}{|c|}{-139.05} & \multicolumn{2}{|c|}{-128.32} & \multicolumn{2}{|c|}{-144.12} \\
\hline \multicolumn{2}{|c|}{$\begin{array}{c}\text { McFadden } \\
\mathrm{R}^{2}\end{array}$} & \multicolumn{2}{|c|}{0.183} & \multicolumn{2}{|c|}{0.163} & \multicolumn{2}{|c|}{0.209} & \multicolumn{2}{|c|}{0.172} \\
\hline \multicolumn{2}{|c|}{$\begin{array}{l}\% \text { of Right } \\
\text { Prediction }\end{array}$} & \multicolumn{2}{|c|}{78.841} & \multicolumn{2}{|c|}{73.186} & \multicolumn{2}{|c|}{75.249} & & 447 \\
\hline $\begin{array}{r}\mathrm{N} \\
\text { Obse }\end{array}$ & $\begin{array}{l}\text { of } \\
\text { tions }\end{array}$ & & & & & & & & \\
\hline
\end{tabular}

〈Table 4〉 Elicited WTP on Dichotomous Choice Method

\begin{tabular}{c|c|c|c}
\hline \multicolumn{2}{c|}{} & WTP truncated & Green Premium \\
\hline \multirow{2}{*}{ Low Price } & Skin Care & 19,152 won & $+27.7 \%$ \\
\cline { 2 - 4 } & Make up & 18,150 won & $+21.0 \%$ \\
\hline \multirow{2}{*}{ High Price } & Skin Care & 59,128 won & $+18.3 \%$ \\
\cline { 2 - 4 } & Make up & 57,666 won & $+15.3 \%$ \\
\hline
\end{tabular}


〈Table 5〉 Elicited WTP on Payment Card Method

\begin{tabular}{|c|c|c|c|c|c|c|}
\hline & & Standard Price & $\begin{array}{l}\mathrm{WTP}_{\text {truncated }} \\
\text { (Premium) }\end{array}$ & Mean & $\mathrm{SD}$ & $\mathrm{t}$-value \\
\hline \multirow{2}{*}{ Low Price } & Skin Care & \multirow{2}{*}{15,000 won } & $\begin{array}{c}17,955 \text { won } \\
(19.7 \%)\end{array}$ & 2.97 & 1.44 & $30.99 * * *$ \\
\hline & Make up & & $\begin{array}{c}17,595 \text { won } \\
(17.3 \%)\end{array}$ & 2.73 & 1.35 & $30.45^{* * * *}$ \\
\hline \multirow{2}{*}{ High Price } & Skin Care & \multirow{2}{*}{50,000 won } & $\begin{array}{c}56,950 \text { won } \\
(13.9 \%)\end{array}$ & 2.39 & 1.36 & $26.47^{* * * *}$ \\
\hline & Make up & & $\begin{array}{c}55,650 \text { won } \\
(11.3 \%)\end{array}$ & 2.13 & 1.13 & $28.22^{* * * *}$ \\
\hline
\end{tabular}

**** $p<0.001$

pay 17, 955 won for low-priced skin care cosmetics, which is $19.7 \%$ higher than the reference price of 15,000 won. The WTP price of low-priced makeup cosmetics is 17,595 won, which is $17.3 \%$ higher than the reference price. The respondents were willing to pay 56,950 won for high-priced skin care cosmetics, which is $13.9 \%$ higher than the reference price of 5000 won. The WTP of high-priced makeup cosmetics was 55,650 won, which is $11.3 \%$ higher than the reference price. In addition, t-test indicated that all four dependent variables were statistically significant on $99.99 \%$ confidence level.

Table 6 and Table 7 presented the frequency table about willingness to pay of the respondent classified by the proposed prices of the reference product. In all cases, the number of the respondents who are willing to pay more for eco-friendly cosmetics tends to decrease as the

〈Table 6〉 WTP of Low Priced Cosmetics on Suggested Price of Payment Card Method

\begin{tabular}{c|c|c}
\hline \multirow{2}{*}{ Suggested Price } & $\begin{array}{c}\text { Low Priced } \\
\text { Skin Care }\end{array}$ & $\begin{array}{c}\text { Low Priced } \\
\text { Make up }\end{array}$ \\
\cline { 2 - 3 } & Frequency $\%)$ & Frequency $(\%)$ \\
\hline 15,000 won $(+0 \%)$ & $33(14.6)$ & $45(19.9)$ \\
\hline 16,500 won $(+10 \%)$ & $59(26.1)$ & $61(27.0)$ \\
\hline 18,000 won $(+20 \%)$ & $75(33.2)$ & $67(29.6)$ \\
\hline 19,500 won $(+30 \%)$ & $20(8.8)$ & $24(10.6)$ \\
\hline 21,000won $(+40 \%)$ & $19(8.4)$ & $20(8.8)$ \\
\hline Over 22,500won $($ over $+50 \%)$ & $20(8.8)$ & $9(4.0)$ \\
\hline Total & $226(100.0)$ & $226(100.0)$ \\
\hline
\end{tabular}


〈Table 7〉 WTP of High Priced Cosmetics on Suggested Price of Payment Card Method

\begin{tabular}{c|c|c}
\hline \multirow{2}{*}{ Suggested Price } & $\begin{array}{c}\text { High Priced } \\
\text { Skin Care }\end{array}$ & $\begin{array}{c}\text { High Priced } \\
\text { Make up }\end{array}$ \\
\cline { 2 - 3 } & Frequency $(\%)$ & Frequency $(\%)$ \\
\hline 50,000 won $(+0 \%)$ & $69(30.5)$ & $76(33.6)$ \\
\hline 55,000 won $(+10 \%)$ & $72(31.9)$ & $85(37.6)$ \\
\hline 60,000 won $(+20 \%)$ & $41(18.1)$ & $37(16.4)$ \\
\hline 65,000 won $(+30 \%)$ & $25(11.1)$ & $20(8.8)$ \\
\hline 70,000 won $(+40 \%)$ & $9(4.0)$ & $4(1.8)$ \\
\hline Over 75,000 won $($ over $+50 \%)$ & $10(4.4)$ & $4(1.8)$ \\
\hline Total & $226(100.0)$ & $226(100.0)$ \\
\hline
\end{tabular}

price of eco-friendly cosmetics rises.

\subsection{The comparison of WTP between dichotomous choice and payment card method}

The results of WTP estimated by dichotomous choice method are compared with those of WTP estimated by payment card method (see. Table 8)
In both the dichotomous choice and payment card method, it showed that the willingness to pay a price premium was higher in order of low-priced skin care, low-priced makeup, highpriced skin care, and high-priced makeup. It means that consumers' WTP is influenced more on the price than on the attributes of the products. Consumers decide the degree of premium based on the price of eco-friendly products, not paying more just because the prod-

〈Table 8〉 Comparison of WTP on Analysis Method

\begin{tabular}{|c|c|c|c|c|c|}
\hline & & \multicolumn{2}{|c|}{ Dichotomous Choice } & \multicolumn{2}{|c|}{ Payment Card } \\
\hline & & Suggested Price & $\begin{array}{l}\mathrm{WTP}_{\text {truncated }} \\
\text { (Premium) }\end{array}$ & Standard Price & $\begin{array}{l}\text { WTP }_{\text {paycard }} \\
\text { (Premium) }\end{array}$ \\
\hline \multirow{2}{*}{ Low Price } & Skin Care & \multirow{2}{*}{ 18,000won } & $\begin{array}{c}\text { 19,152won } \\
(+6.4 \%)\end{array}$ & \multirow{2}{*}{ 15,000won } & $\begin{array}{c}\text { 17,955won } \\
(19.7 \%)\end{array}$ \\
\hline & Make up & & $\begin{array}{c}\text { 18,524won } \\
(+2.91 \%)\end{array}$ & & $\begin{array}{c}\text { 17,595won } \\
(17.3 \%)\end{array}$ \\
\hline \multirow{2}{*}{ High Price } & Skin Care & \multirow{2}{*}{ 57,500won } & $\begin{array}{c}\text { 59,128won } \\
(+2.83 \%)\end{array}$ & \multirow{2}{*}{ 50,000won } & $\begin{array}{c}\text { 56,950won } \\
(13.9 \%)\end{array}$ \\
\hline & Make up & & $\begin{array}{c}\text { 57,666won } \\
(+0.29 \%)\end{array}$ & & $\begin{array}{c}55,650 \text { won } \\
(11.3 \%)\end{array}$ \\
\hline
\end{tabular}


ucts are eco-friendly.

The attributes of the products also have influences on the WTP of eco-friendly cosmetics.

Both low-priced and high-priced products have higher WTP premium on skin care cos$^{-}$ metics than makeup cosmetics. It means that consumers are willing to pay more for eco-friendly skin care cosmetics than for eco-friendly makeup cosmetics. Through face to face interview, respondents were asked the reason why they choose those prices. Interview indicated that consumers are recognized that skin care cos$^{-}$ metics influence directly on their skin. So, while the products are produced in same eco-friendly ingredients, they preferred the skin care cosmetics.

The WTP estimated by dichotomous choice method is higher than the WTP estimated by payment card method. The reason is that the price proposed by dichotomous choice question itself started at the high premium price. On the dichotomous choice method, the reference price was 15,000 won, but the proposed price was 18,000 for high-priced products, which was 20\% higher than the reference price.

However, the WTP price of the payment card method is relatively lower than the WTP price of the dichotomous choice method. The survey questions of payment card method stated both the price premium of the eco-friendly products and the price of reference product. Because of that, consumers seem to have enough time to consider the price premium of the products.

\subsection{Factors that influences consumers' willingness to pay for eco-friendly cosmetics}

In this study consumer's age, educational level, monthly income, marital status, having children or not, job, experience of purchasing eco-friendly products and concerns on environment were used as independent variables that influences consumers' willingness to pay a premium for eco-friendly products. Based on dichotomous choice of CVM, Log-Logit analysis was conducted on each dependent variable (i.e. lowpriced skin care products, high-priced skin care products, low-priced makeup products, and high-priced makeup products.) The findings showed that age, monthly income, and having children or not were statistically significant factors that influence four dependent variables. This study proposed that consumer's experience of purchasing eco-friendly products and concerns on environment would be important factors for willingness to pay a premium for eco-friendly products. However, the results showed that experience of purchasing eco-friendly products and concerns on environment were not statistically significant factors. Other independent variables such as education, marital status, and job did not show any statistical significance. 


\section{Implications and limitations}

The major contribution of this study is the investigation of the value of green attributes of the products by using contingent valuation method. This study contributes to expand the use of CVM as a method of estimating the value of various products. While most previous studies which investigate willingness to pay (WTP), usually used only one survey format of CVM, this research used two formats, the dichotomous choice and the payment card, then it enhance the reliability of research.

The study findings can be used as basic information to establish marketing strategies for green cosmetics. This study showed that consumers were willing to pay more for low-priced products. However, the supply of low-price green cosmetics is not sufficient in cosmetic market. For cosmetics companies, it is reasonable to consider developing distribution channels such as a discount mart.

According to this study findings, consumers showed price sensitivity when they pay green premium. A respondent stated in face to face interview, "I am willing to pay green premium. But higher price which changes the front digit of the amount, is not attractive." In this study the WTP for the low-price cosmetics with the reference price of 15,000 won did not exceed 15,000 won and the WTP for the high-price cosmetics with the reference price of 50,000 won did not exceed 60,000 won. These findings may help cosmetics companies to establish the pricing strategy.

Women with children are suitable for the target group for green cosmetics. The result of this study showed that women with children were willing to pay more for high-priced green cosmetics. Thus, high-priced green cosmetics in department store would be more appealing to the women with children.

This research has some limitations followed. First, the sample of this study is limited to women residing in Seoul and Gyeonggi, Korea. Therefore, it is hard to generalize the findings to overall Korean consumer. Thus, additional studies on attitudes and the WTP of men for green products are needed. Second, consumers' behaviors in real situations may differ from consumers' responses. It is the limitation of contingent valuation method eliciting responses from hypothetical purchase situation. Third, in order to prevent bias of the product, this study selected consumable supplies, which cycle of use is short. So it is hard to generalize the findings to all of the products in market. The willingness to pay a premium for green durable goods may differ from the WTP for green cosmetics.

〈Received November 6. 2013〉

〈Revised December 11. 2013〉

〈Accepted December 16. 2013〉 


\section{References}

Alwitt, L., \& Pitts, R. (1996). "Predicting Purchase Intentions for an Environmentally Sensitive Product," Journal of Consumer Psychology, 5(1), 49-64.

Ba, S. L., \& Pavlou, P. A. (2002). "Evidence of the Effect of Trust Building, Technology in Electronic Markets: Price Premiums \& Buyer Behavior," MIS Quarterly, 26(3), 243-268.

Chase D., \& Smith, T. K. (1992). "Consumers Keen on Green But Marketers Don't Deliver," Advertising Age, 63(6), S2-S6.

Follows, S. B., \& Jobber, D. (2000). "Environmentally Responsible Purchase Behavior," European Journal of Marketing, 34(5/6), 723-746.

Ha, H. Y. (2012). "A Study of Consumer Purchase Intentions on Environmetally-Friendly Sustainable Glass: The Moderating Role of Price Premium," The Academy of Customer Satisfaction Management," 14(2), 85-105.

Huh, S. W., \& Kim, H. (2004)." Analysis of Willingness to Pay of Eco-friendly Product and Green Marketing Strategy," Korean Journal of organic Agriculture, 12(3), 317331.

Lalit, M. J., \& Sahasakmontri, K. (1998). "Green Marketing of Cosmetics and Toiletries in Thailand," Journal of Consumer Marketing,
15(3), 265-281.

Landler, M. (1991). “Suddenly, Green Marketers Are Seeing Red Flags," Business Week, Feb(25), 74-76.

Lee, C. K. (2006). Value Estimation of Ecological Tour Resources by Two Step CVM Approach," Korean Journal of Hospitality, 25(3), 173-187.

Lee, C. M., Lee, J. S., K. D. S., K. J. S., \& Lee M.H. (2008). "Estimation of Willingness to Pay to U-Eco Housing Complex Using by Conditional Value Method," Journal of the Korean Planners Association, 43(3), 237248.

Moon, S. J. (2009). Consumer Perception of EcoFriendly Management System, Ewha Womans University Masters' Thesis.

Kim, H., \& Jang, K. Y.(2008). "Purchase Intention and Estimation of Willingness to pay of Organic Korean Beef," Korean Journal of organic Agriculture, 16(4), 367-390.

Kim, I. S., \& Kim, E. C. (1999). “A Study on the Relationship Between the Price Premium and the Perceived Quality Evaluation," Industrial Information Institute, 12(6), 1330.

Kleiner, A. (1991). "What Does It Mean To Be Green?" Harvard Business Review, 69 (4), 38-47.

Oberholtzer, L., Dimitri, C., \& Greene, C. (2005). Price premiums hold on as U.S. organic produce market expands. Electronic Outlook Report from the Economic Research Service. 
Retrieved from http://www.ers.usda.gov/ publications/vgs/may05/vgs30801/vgs30801. pdf.

Ottman, J. A. (1994). Green Marketing, NCT Business Books, Chicago, IL.

Pearce, F. (1990). "The Consumer Are Not So Green," New Scientist, 13, 14.

Rao, A. R., \& Bergen, M. E. (1992). "Price Premium Variations as a Consequence of Buyers' Lack of Information," Journal of Consumer Research, 19, 412-423.

Usitalo, L. (1990). "Are Environmental Attitude and Behavior Inconsistent," Scandinavian Political Studies, 13(2), 211-226.
Yoo, S. J., Lee, H. J., \& Kim, Y. H. (2011). "A Study on the Relationships Among Sought Benefits, Purchase Experience, and Brand Relationship in Case of Cosmetics, "Asia Marketing Journal, 13(2), 73.89.

Yoo, E. Y., \& Ko, J. Y. (2008). "Effect on Service Quality on Trust and Premium Price in 5-Star Hotel Restaurants in Seoul," Journal of Hospitality and Tourism Studies, 10(3), 130-142. 